\title{
TUBG1 wt Allele
}

National Cancer Institute

\section{Source}

National Cancer Institute. TUBG1 wt Allele. NCI Thesaurus. Code C52449.

Human TUBG1 wild-type allele is located in the vicinity of $17 q 21$ and is approximately $6 \mathrm{~kb}$ in length. This allele, which encodes tubulin gamma-1 chain protein, is involved in the modulation of microtubule assembly. 